\title{
Impact of Ribbon Development on Land Use along Dhaka Aricha Highway. The Case of Savar Upazila
}

\author{
Md. MAHMUDUL HASAN' 1 , S. M. NAWSHAD HOSSAIN', Tanvir AHMAD' \\ ${ }^{1}$ Jahangirnagar University, Department of Urban and Regional Planning, Dhaka, BANGLADESH \\ E-mail:mmhasan39@gmail.com, nawshad_urp@yahoo.com, tanvir12urp@gmail.com \\ DOI: 10.24193/JSSP.2017.1.01 \\ https://doi.org/10.24193/JSSP.2017.1.01
}

K e y w o r d s: ribbon development, rapid urban growth; land use change, Dhaka Aricha highway

\begin{abstract}
A B S T RACT
Savar, one of the suburbs of Dhaka is undergoing tremendous development due to rapid urbanisation. Better access due to Dhaka Aricha Highway integrating with the development process has led augmentation of ribbon development. This type of development is very much attractive to developers in the sense that they do not have to waste money or plot space for constructing roads and can attract trade from the traffic on arterial roads. But the emergence of fringe zones and their complex, as well as unplanned ribbon development along Dhaka Aricha Highway, has led to serious land use problems such as haphazard urban growth, loss of agricultural lands, encroachment of water bodies, unauthorised urban sprawl, the rapid increase in land values, speculation in land and other related problems. Besides, the option for future planned development and provision of service along the Dhaka Aricha Highway is being jeopardized. In this consequence, this study attempts to focus on the trend of ribbon development along Dhaka-Aricha Highway to show the impact on the land use. To assess the trend in land use change, satellite image of four base years $(2007,2010,2013$ and 2016) of the study area were analysed by Geographical Information System (GIS) tool. Finally, a number of recommendations have been formulated to reduce the adverse impact of ribbon development.
\end{abstract}

\section{INTRODUCTION}

Today road transportation has become the most important means of communication and all development efforts are therefore concentrated towards planning, design and construction of the nation-wide network of roads at all levels [1]. Urban areas grow centrifugally with major transport routes having a dominant influence on the direction of physical expansion. Strong links between urban areas and suburban or rural areas support the expansion along the major roads [2] which is termed as ribbon development. Commercial establishments, industrial plants, residential areas and other functions tend to locate along these roads because construction costs usually necessitate construction on sites with minimal slopes [3]. Potential urban development is alleged to be a threat to the existence of agriculture [2] and wetland in the rural-urban fringe along the road. Savar is the first suburb in the north-west of Dhaka city [4]. DhakaAricha road (which is one of the main highways that connects several divisions in Bangladesh) runs through the urban centre of Savar Upazila [5] and serves as the main artery of vehicular transport of Savar. Savar has a lucrative location for the industries because of its short distance from Dhaka. Besides, availability of communication facility (due to Dhaka Aricha Highway) has also prompted many people working in the capital to set up their permanent residence in Savar [6]. In this case, the land near to Dhaka - Aricha Highway offered excellent access to the people [4] and available vacant cheap land along it encourages large-scale industrial, commercial and residential developments. With all those issues Savar is turning into a gigantic form especially through horizontal expansion along DhakaAricha Highway. However, this expansion has 
happened haphazardly, and by violating the environmental laws and ignoring overall public convenience, not to speak of the care for future urban growth. Valuable agricultural lands and watercourses are being encroached by land filling for industrial, residential, commercial and other infrastructure development processes. These developments are also affecting the direction of urban growth and future planning decisions, causing the uneconomical extension of utilities, environmental degradation, scenic quality damages, and traffic problems

This research aims at making a trend analysis of ribbon development along the Dhaka Aricha Highway from 2007-2016 to find out an exact scenario of land use changes and its impacts. Finally, some suggestions will be formulated to reduce the future probable impacts.

\section{STUDY AREA}

Savar is geographically located between $23^{\circ} 44^{\prime}$ 15.61" and $24^{\circ} \mathrm{O} 1^{\prime} 37.17^{\prime \prime}$ North and between $90^{\circ} 11^{\prime} 08.45^{\prime \prime}$ and $90^{\circ} 21^{\prime} 36.70^{\prime \prime}$ East.

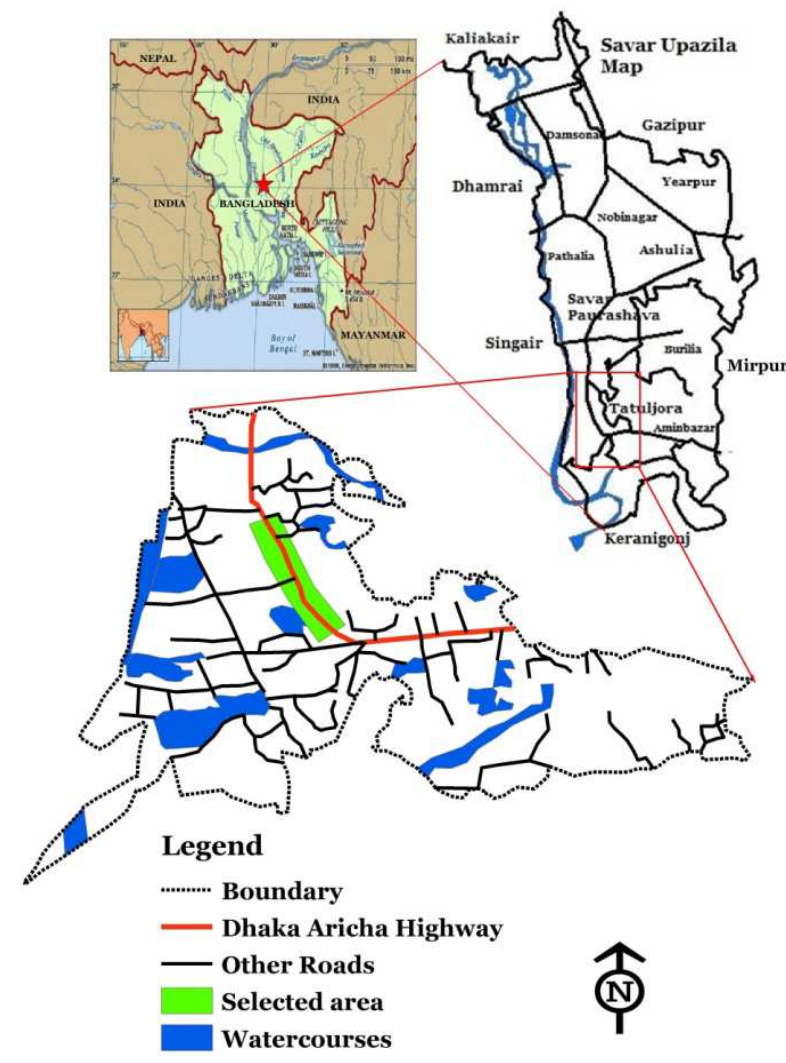

Fig. 1. Location map of Savar.

The Upazila occupies an area of $280.12 \mathrm{sq} . \mathrm{km}$, including 20 sq. $\mathrm{km}$ of river and $8 \mathrm{sq}$. $\mathrm{km}$ of forested area [7]. According to the BBS 2011, the population of Savar Upazila was $1,385,910$ [8]. It has a rapidly growing population and has experienced a change in its traditional agrarian land use during the last few decades due to rapid urbanisation and industrialisation. Since
1995, the study area has come within the jurisdiction of the RAJUK. Dhaka-Aricha highway is the main transit route of Savar which covers about $30 \mathrm{~km}$ in the Upazila. Its construction has triggered massive change of the landscape [9]. There is a debate as to whether Savar Upazila should be considered as a rural or urban domain. Because it is part of the RAJUK, and a municipality, various big government infrastructures are located here with urban facilities [9]. Moreover, the Agriculture Census of 2006 [8] recorded it as an urban domain. But the area is not completely rural and not a completely urban area. Rashid (2001) preferred to define the Upazila as a pro-urban area which has been transforming very quickly in the last decades [9]. To define the impact of ribbon development in Savar, Tatuljora, one of the unions of Savar Upazila [10] was selected as a sample area as it is going under rapid land use change due to ribbon development.

\section{AIMS AND OBJECTIVES OF THE STUDY}

The principal aim of this research is to examine the impact of ribbon development along Dhaka-Aricha on land use. In short, the specific objectives are as follows:

a). To focus on the existing scenario of ribbon development along the Dhaka-Aricha Highway.

b). To determine the impacts of ribbon development on land use in the study area.

c). To propose some guidelines to improve the present condition of unplanned ribbon development in the study area.

\section{LITERATURE REVIEW}

Ribbon development is one of the striking features of human geography and expanding to an extraordinary degree in everywhere. Northern Ireland Regional Planning Policies (1993) defined ribbon development as a line of buildings, served by individual accesses, extending along a road, by the effect of urban and industrial dynamics [2], without accompanying the development of the land to the rear [11].

Rashid (2001) presented a trend of land-use change in Savar [9]. The analysis of this trend shows that Savar Upazila was untouched by any infrastructural development until the 1950 s and was a complete agro-based rural system in a traditional predevelopment phase. In the early 1960s, the first development was triggered by construction of the national highway and a significant amount of land was acquired by the government for the infrastructural developments in the heartland of the Upazila. Masud (2008) also analyzed the trend of land use change in the Savar municipality [12]. The study concluded that the open spaces and agricultural lands are gradually being transformed into residential or commercial and industrial uses. 
Due to rapid urbanisation, Dhaka has been left with 19.3 percent of its wetlands and if the current rate of wetland loss continues, by the year 2037 all temporary wetlands of Dhaka will disappear [13]. In this context, Akter and Hossain (2011) studied the impacts of unplanned housing development in the Flood Flow Zones of Tatljora and suggested measures in order to prevent such illegal development [10].

Tariq and Jinia (2012) investigated the relationship between the integration core of transport and existing land use categories at Savar through space syntax analysis [5]. The analysis concluded that the integration between the transport and land-use is very high along the Dhaka Aricha Highway.

\section{WORKING METHODOLOGY}

The study of urban ribbon development presents a unique area of geographic analysis. It is an attempt to determine the origin, elements and significance of the sprawl extending outward from the urban centres [14] along the roads. But the problem arises as to what methods can be used to study the impact of ribbon development. For this research, although data from both primary and secondary source has been collected, the prominent emphasis was put on satellite image analysis by GIS tool to show the impact of ribbon development on land use because it is very difficult to find out the trend in land use change of any area by field survey. The analysis of land parcel data by applying Geographic Information System (GIS) software enables planners to better understand the locational and spatial characteristics of a land area, along with its social, economic and environmental dimensions [15].

In this research, Arc Info Software was used as a tool of GIS for analysing satellite image to find out the trend in land use change. The whole working steps are as follows:

Step 1: Collection of Satellite Image: To show the trend in land use change along Dhaka Aricha
Highway four satellite images of the study area have been taken within an interval of three years (e.g. 2007, 2010, 2013 and 2016).

Step 2: Geo-referencing: To match the digitised land uses with the actual scale, each image was georeferenced by taking a sufficient number of Ground Control Points (GCPs). Then the images were projected onto a plane, then rotated and scaled to a map projection system.

Step 3: Data Analysis: Each image was then taken on the platform of Arc GIS tool and the highway section was digitised. Then a buffer zone was created within the 300-meter distance along the highway. The land use options within the buffer zone were digitised and the area was calculated. Thus, the actual area of the built up areas, vegetation/ agricultural lands, watercourses and land filled for the development of four base years was collected. Finally, each base year image was compared to each other to find out the exact land use change scenario of the study area.

\section{EXISTING SCENARIO OF RIBBON DEVELOPMENT ALONG DHAKA ARICHA HIGHWAY}

Ribbon development takes place when extensive residential / commercial / industrial development occurs in a linear pattern along both sides of arterial roadways [16]. According to Rangwala (1999), ribbon development is one of the natural forms of urban growth according to direction [17]. It is the most common form of urban growth in our country, especially along the Dhaka-Aricha Highway. For this research, a detailed survey was conducted to find out an exact scenario of ribbon development along the DhakaAricha Highway. Based on this survey, we found that most of the developments along the Dhaka-Aricha Highway are industrial in nature although there are some residential or commercial developments in a mixed form. The detailed land use scenario along both sides of the road is shown in the following table.

Table 1. Type of Land-uses by the both Side of Dhaka Aricha Highway: A. Residential, B. Commercial, C. Manufacturing, D. Institutional, E. Mix, F. Others.

\begin{tabular}{|c|c|c|c|c|c|c|c|}
\hline \multirow{2}{*}{ Tatuljora } & \multicolumn{7}{|c|}{ Type of Land-use (\%) } \\
\hline & $\mathbf{A}$ & B & $\mathbf{C}$ & D & $\mathbf{E}$ & $\mathbf{F}$ & Total \\
\hline $\begin{array}{l}\text { West side of the } \\
\text { road }\end{array}$ & 8 & 5 & 72 & 1 & 11 & 3 & 100 \\
\hline $\begin{array}{l}\text { East side of the } \\
\text { road }\end{array}$ & 11 & 10 & 67 & 5 & 7 & 0 & 100 \\
\hline
\end{tabular}

Availability of vacant lands both low and high at a comparatively cheap rate, easy accessibility to the main road as well as abundant and cheap labour are the main factors causing large scale industrial developments along Dhaka-Aricha Highway in
Tatuljora. The structural form of industrial and commercial developments is usually pucca $(75 \%)$ or semi-pucca (17\%) in nature but there are some slums or illegal encroachments which are a catch (9\%) in nature. As industrial development requires permanent land 
parcel, most of the industries are established in owned lands (78\%). Besides, there are some rented commercial developments (18\%). Some government-owned vacant lands and wetlands are encroached by the unauthorised occupier (usually slums) which is $4 \%$ of the total land.

As ribbon development along Dhaka-Aricha Highway is extending in a long strip, the authority finds it difficult to provide the basic services (water supply, electricity, postal deliveries, telephone, etc) in this area. During the primary investigation, it has been found that most of the development has its own operating water supply system. The unplanned expansion of settlements only along the main road is sterilising backlands by hampering the planned expansion of settlements in future.

\section{RESULTS AND DISCUSSIONS}

In this research, the trend of ribbon development in Tatuljora from the year 2007 to 2016 has been analysed. As there are no previous data about ribbon development along Dhaka Aricha Highway, the satellite images of different years of the study area were analysed by GIS tool to find out the trend. The land use trend analysis of the study area is shown in the following table.

Table 2. Trend in land use change from 2007-2016.

\begin{tabular}{|c|c|c|c|c|c|c|c|c|}
\hline \multirow[b]{2}{*}{ Landuses } & \multicolumn{2}{|c|}{2007} & \multicolumn{2}{|c|}{2010} & \multicolumn{2}{|c|}{2013} & \multicolumn{2}{|c|}{2016} \\
\hline & $\begin{array}{c}\text { Total } \\
\text { land area } \\
\text { (ha) }\end{array}$ & $\begin{array}{c}\% \text { of land } \\
\text { use }\end{array}$ & $\begin{array}{l}\text { Total } \\
\text { land area } \\
\text { (ha) }\end{array}$ & $\begin{array}{c}\% \text { of land } \\
\text { use }\end{array}$ & $\begin{array}{c}\text { Total } \\
\text { land area } \\
\text { (ha) }\end{array}$ & $\begin{array}{c}\% \text { of land } \\
\text { use }\end{array}$ & $\begin{array}{c}\text { Total } \\
\text { land area } \\
\text { (ha) }\end{array}$ & $\begin{array}{c}\text { \% of land } \\
\text { use }\end{array}$ \\
\hline $\begin{array}{l}\text { Agricultural Land/ } \\
\text { Vegetation }\end{array}$ & 54.12 & 62 & 43.85 & 50 & 33.94 & 39 & 25.05 & 28 \\
\hline Watercourses & 17.13 & 19 & 11.84 & 14 & 9.64 & 11 & 7.71 & 9 \\
\hline $\begin{array}{l}\text { Land filled or } \\
\text { development }\end{array}$ & 4.27 & 5 & 8.1 & 9 & 6.48 & 7 & 5.1 & 6 \\
\hline Built up area & 12.09 & 14 & 23.82 & 27 & 37.55 & 43 & 49.75 & 57 \\
\hline Grand Total & 87.61 & 100 & 87.61 & 100 & 87.61 & 100 & 87.61 & 100 \\
\hline
\end{tabular}

\subsection{Land use analysis of the base year (2007)}

The data analysis illustrates that before 2007 the land use of Tatuljora was dominated by agricultural lands (62\%) and there was a significant amount of watercourses (19\%). The built up area was only $14 \%$ in 2007. After 2007 a great amount of agricultural lands and watercourses have been filled for development purposes (5\%). The total land use scenario of Tatuljora in 2007 is presented in Figure 2.

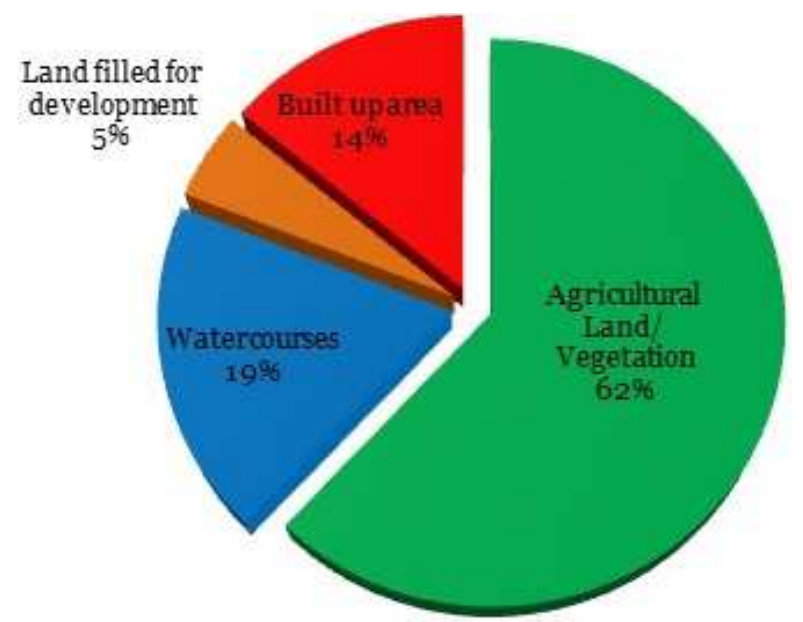

Fig. 2. Percentage of land use in 2007.

\subsection{Land use trend analysis from $2007-2010$}

In 2010, the size of agricultural land was of 43.85 ha ( $50 \%$ of total land use). It indicates that about $12 \%$ agricultural lands were lost to development by 2010.

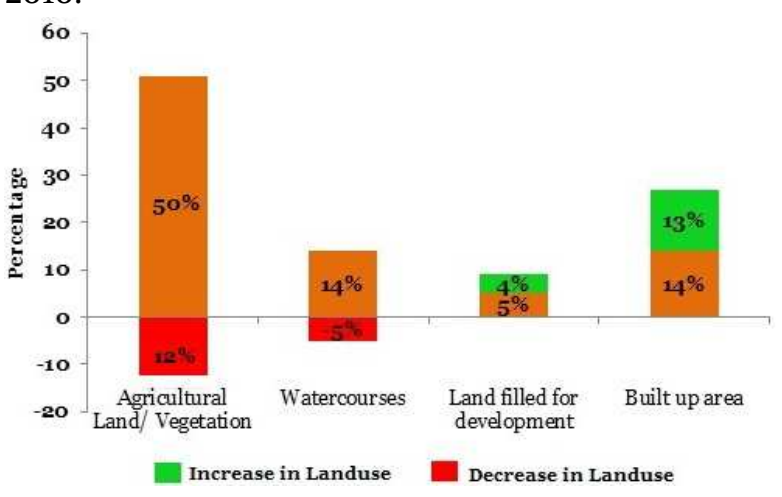

Fig. 3. Trend in land use change from 2007-2010.

The total percentage of the watercourses in 2010 was of $14 \%$ (11.84 ha) which means that about $5 \%$ of watercourse area was lost within this time interval (17.13 ha). Of this $4 \%$ has been filled for future development and rest (1\%) has already been developed as built-up area. On the other hand, the percentage of 
built up area in 2010 was about $27 \%$ (23.84 ha) which indicates a $13 \%$ of land has transformed either from agricultural lands or watercourses to build up areas in respect to 2007.

\subsection{Land use trend analysis from 2010-2013}

In 2013, the amount of agricultural land was 33.94 ha (39\% of total land use). It indicates that about $11 \%$ agricultural lands were decreased with respect to 2010.

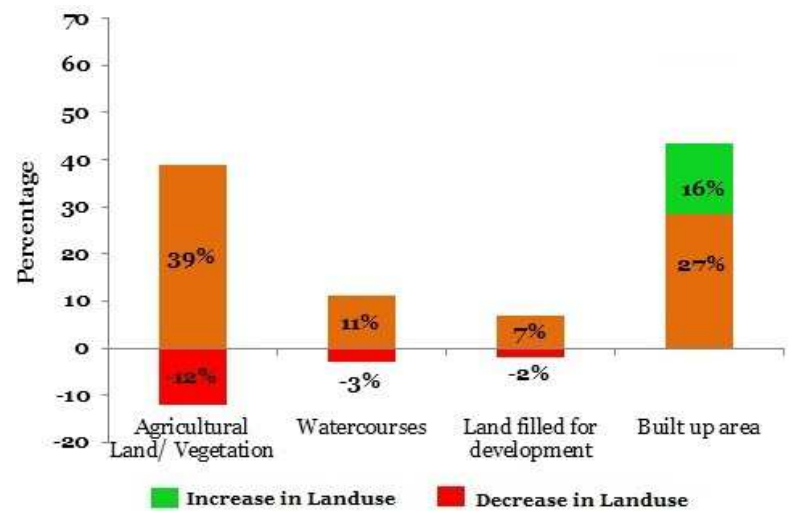

Fig. 4. Trend in land use change from 2010-2013.

The total percentage of the watercourses in 2013 was $11 \%$ ( 9.64 ha) that means about $3 \%$ of watercourses were decreased than that of $2010(11.84$ ha). In 2010 the land filled for development was $9 \%$ of total land use (8.1 ha). But in 2013, the land filled for development was $7 \%$ of total land use and the rest $2 \%$ has been added to the built up area. On the other hand, the percentage of built-up area in 2013 was about $43 \%$ (37.55 ha) which indicates that about $16 \%$ of lands has transformed to build up areas.

\subsection{Land use trend analysis from $2013-2016$}

In 2016, the amount of agricultural land was 25.05 ha ( $28 \%$ of total land use). It indicates that about $11 \%$ agricultural lands were decreased with respect to 2013 .

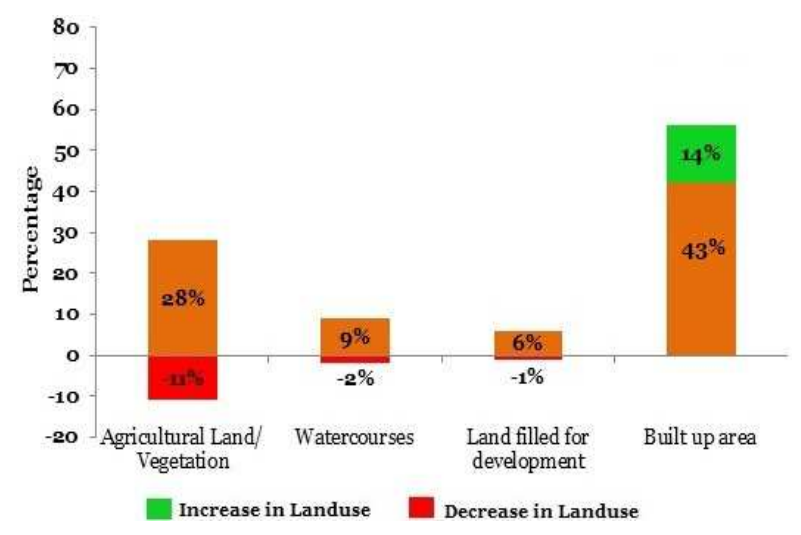

Fig. 5. Trend in land use change from 2013-2016.

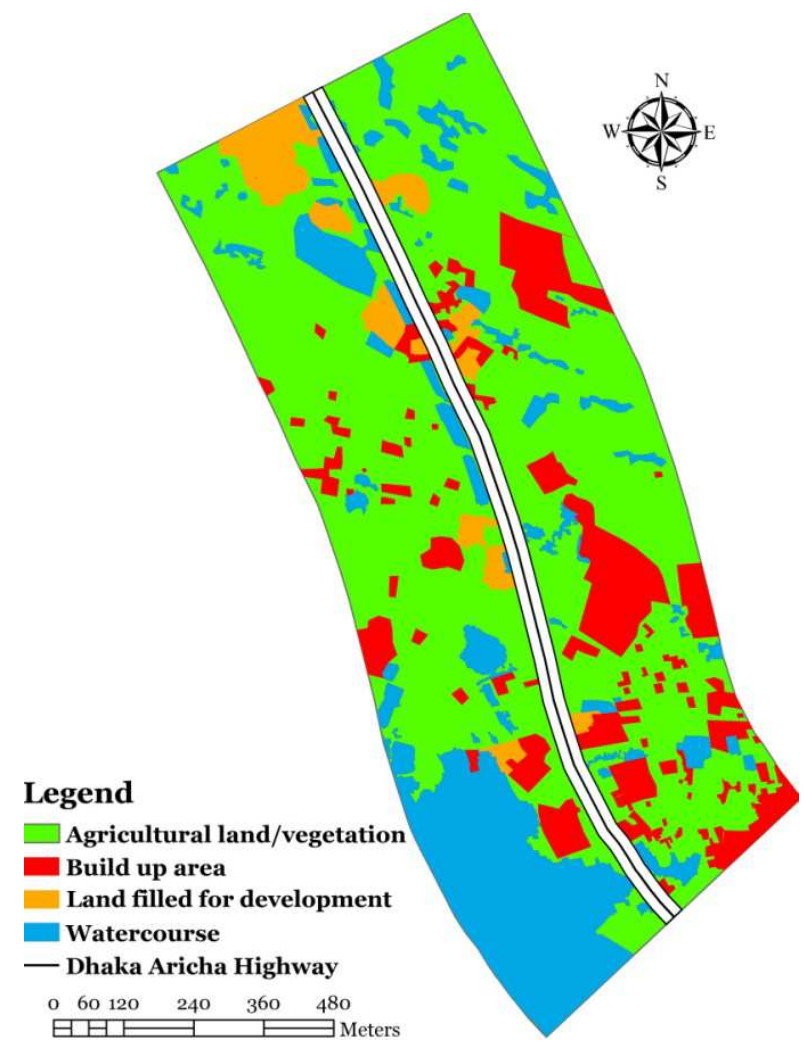

Fig. 6. Land use map of Tatuljora along DhakaArikha highway in 2007.

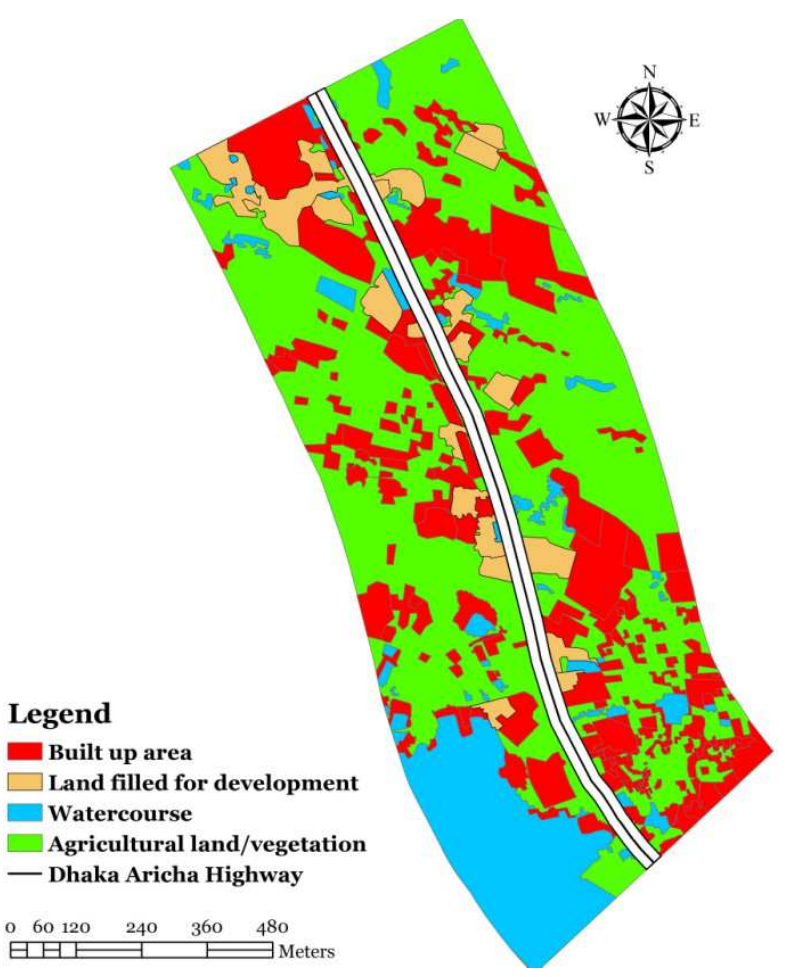

Fig. 7. Land use map of Tatuljora along DhakaArikha highway in 2010.

The total percentage of the watercourses in 2016 was $9 \%(7.71 \mathrm{ha})$ that means about $2 \%$ of watercourses were decreased than that of 2013 (9.64 ha). In 2013 the land filled for development was $7 \%$ of total land use (6.48 ha). But in 2016, the land filled for 
development was $6 \%$ of total land use and the rest $1 \%$ has been added to the built up area. On the other hand, the percentage of built-up area in 2016 was about $57 \%$ (49.75 ha) which indicates that about $14 \%$ of lands has transformed to build up areas.

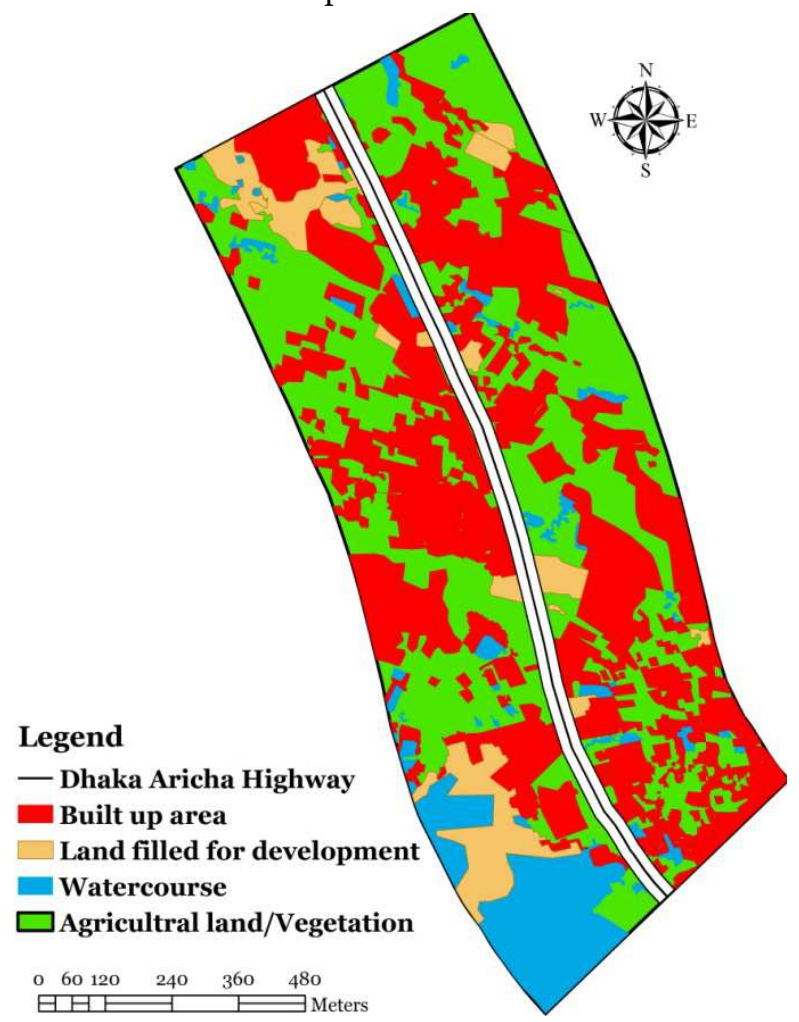

Fig. 8. Land use map of Tatuljora along DhakaArikha highway in 2013.

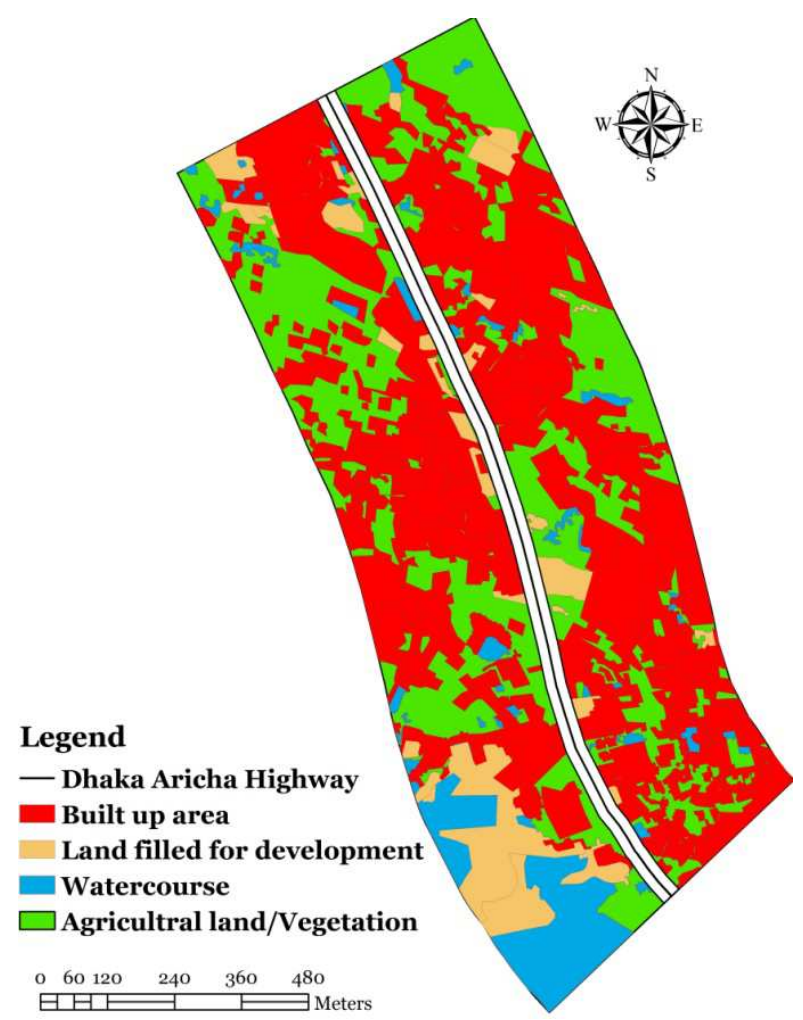

Fig. 9. Land use map of Tatuljora along DhakaArikha highway in 2016.

\subsection{Land use change from $2007-2016$}

The elaborated maps illustrate a comparison of the land use changes in different years (from 2007 to 2016).

Impacts of ribbon development on land use. Population growth will determine big cities to either grow vertically or expand horizontally. Planning discipline aims to control and direct those developments within optimum spaces. Due to lack of proper zoning along the highway and lack of control measures, ribbon development can be considered as the reverse of good planning in the study area. The impact of ribbon development along in the study area is described below.

Loss of vegetation/agricultural land. In the process of ribbon development, a huge tract of agricultural land and vegetation along the main road of the study area is rapidly being converted into different urban land uses (mostly industrial or commercial in nature). Uncontrolled agricultural/vegetation land conversion has adverse impacts on the environment in general and agricultural products in particular [18].

Encroachment of water bodies. The wetlands (such as depressions, abandoned channels, and lowlying areas) act as natural sponges [19] that retain excess storm runoff or overflow of rivers thus delaying and lowering the flood peak and also slowing down the average speed of the flood water [20]. Besides, water bodies, the aquatic systems on land, are one of the important store houses for variety of wildlife as well as nesting and breeding sites for different kind of avifauna [21]. In the past, open spaces and depressions (i.e. water bodies) had dominated the land use of the study area, but due to rapid urbanisation this scenario is changing very fast. As this type of land is comparatively cheaper than that of the highland areas, it is now facing the axe of development process mostly by filling of the earth. Filling of those watercourses is causing frequent flooding, heat stress and loss of biodiversity in this area.

Increase in the land price. Change in the land prices is one of the social and economic impacts of agricultural land conversion [18] and filling of wetlands. In rural-urban fringe areas like Tatljora especially such changes near to highways are accompanied by frequent land ownership transfers and landmark changes in land prices. There is direct competition between rural and urban land uses in that part of the landscape. Generally, urban land use takes over as the comparatively higher price can be offered for land for urban development than for rural use [4]. The land use of Tatuljora along Dhaka- Aricha Highway is being changed so quickly due to rapid ribbon development that is causing an increase in land price overnight. Within 5-10 years land prices could double or even triple. The increase of registered land price of the study area from the year 2007 to 2016 is shown in figure 10. 


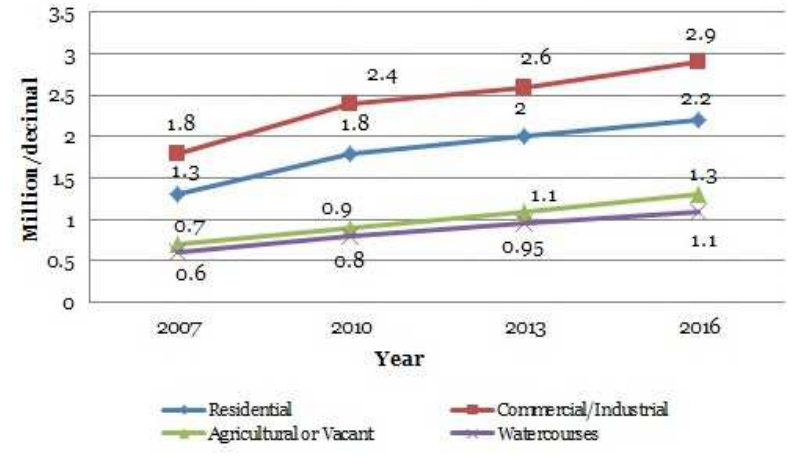

Fig. 10. Trend in land value change from 2007 to 2016.

The above figure shows the registered land price change in the study area, but the actual price of the land is higher than the price registered. The government set a land price for a certain area as a whole. But the lands along the road are so attractive that the transfer of those lands cannot match the prescribed rate. Besides, due to rapid conversion of land use along the main roads, there is a huge difference between actual land price and the government settled land price.

Damaging the scenic view. The damage in the scenic quality along the roads by the effect of ribbon developments is resulting from the lack of validity of planning and architecture disciplines. There are illegal encroachments of small shops or slum activity which really impair the vista of the roadside.

Uneconomic extension of urban service. The existing service line of Savar Upazila is expanding in a linear pattern due to the existence of Dhaka-Aricha Highway. The urban area is expanding in a horizontal pattern along the highway with an absence of compact development in the surroundings. To cater those developments with services such as water supply, gas, sewerage system etc. the authority has to expense a lot as the number of lines is limited. In many cases the owner of land parcel (such as in Tatuljora) has to manage his/her own water supply system, sewerage system, drain or need for fire as the authority do not provide these services due to the high costs involved and the limited number of consumers.

\subsection{Recommendation}

Land speculators, landholders, builders, financial institutions, private companies and all buyers of residential property are engaged in changing land from some open or less intensive use to urbanised use [4]. Due to this reason the land use changes in suburban areas have important implications for longterm public land use planning. The city and regional planners, therefore, should try to prevent the growth of undesirable land use patterns which may twist or impact the surrounding land uses. To control the ribbon development not only along the Dhaka Aricha Highway but also every national highway the following measures have been suggested.

a). Need for a planned development: Land transformation in Savar Upazila is an ongoing natural, spontaneous process where raw agricultural lands are being transformed into structural development but in an unplanned way. Roadside lands are developed in an unplanned manner and at a fast rate for industrial or commercial uses. Therefore, a reform in planning and development is an urgent need.

b). Promulgation of ribbon development act. Although there is a huge pressure of ribbon development along the national highways of Bangladesh, there are no specified rules and regulations regarding ribbon development for the fast-growing cities and towns. Even in the National Highway Act, 1956 there is no mentioning of the need for adequate planning consideration to control ribbon development [22]. So, Restriction of Ribbon Development Act is an urgent need. Besides, National Highway Act, 1956 should be specified to control ribbon development along the highway.

c). Provision of extra land along the highway for future development. Development is a continuous process and needs to be adjusted from time to time. During development of an area, sustainable planning concepts must be considered or the present beautiful developments will be a curse in the future. From this view, along every highway, adequate land should be left for future needs. One of the most effective methods of ensuring that ribbon development does not exist and land for the future requirement is preserved is to acquire extra land along the roadway by the government. For an example, to cope up with the future land use problems, in 1960's in Delhi, 66,000 acres of land around the periphery were acquired by the government for development and to face the future requirements [4].

d). Land use zoning along highway. A landuse zoning system along the Highway should be introduced by the Roads and Highway Department (RHD) for controlling the future occurrence of unplanned ribbon developments.

e). Buffer zone between the road and development. According to the National land-use Policy, 2001, there must be a buffer zone or green belt of 10-20 feet in width with appropriate vegetation between the control line and the building line of the road [23]. This zone will reduce the illegal encroachment of the road and provide a beautiful aesthetic view of the road.

f). Control of building development activities. The rapid pressure of ribbon development in an unplanned way along the national highway cannot be reduced without taking any control measures by the government or municipal authority. It is desirable that 
within a prescribed distance from the highway no building activity be allowed. This distance from the road is defined by a hypothetical line (building line). According to the Bombay Highways Act, 1955, the setback distance between building activity and the road is 3-6 $\mathrm{m}$ in the urban area [24]. However, for the rural areas, the building line distance should be of 80 meters and the control line distance should be of 150 meters. Beyond this line, it is desirable that buildings of a height exceeding 13 meters above road level not to be built.

\section{CONCLUSION}

There is no doubt that ribbon development has a negative connotation due to the impact on the open countryside of Savar. Due to rapid urbanisation and industrialisation, speculation of the lands along the Dhaka-Aricha Highway is increasing swiftly. But the environmental issues has led those speculations to change the agricultural lands and wetlands in a crucial manner. The process of ribbon development has further accentuated by uncontrolled proliferation of access points and unplanned commercialization to the DhakaAricha Highway. So planning authority both at local and national level must be concerned about this issue. Legislative steps should have been taken to impose the ban on ribbon development or permit under planning consideration. During the approval of a development activity, profound examination of both environmental and the sustainable planning issues must be considered. Then we will be able to create a planned urban development in a suburban area of Dhaka, Savar.

\section{REFERENCES}

[1] Shafi, S. A. (2012), Land-use planning along national and regional highways, The Newage, pp. 10. Available at: http://www.newagebd.com/special .php?spid =2\&id =4. Last accessed: April 30, 2016.

[2] Kilinc, G. (2000), Ribbon developments in Aydin along Denizli-izmir Highway, Izmir Institute of Technology, Izmir, Turkey. Available at: http://library.iyte.edu.tr/tezler/master/sehirplanlama/ Too0118.pdf. Last accessed: February, 30, 2016.

[3] Deng et al. (2006), Growth, population and industrialization and urban land expansion of China. Center for Chinese Agricultural Policy, Institute of Geographical Sciences and Natural Resources Research, Chinese Academy of Sciences, Beijing 100101, China. Available at: http:// iisdb.stanford.edu/pubs/21644 /Growth_Pop_and_Industrial_and_Urban_Land_Exp ansion_forthcomingJUE.pdf Last accessed: June, 18, 2016.

[4] Chowdhury, M. R. (1990), Land Use Transformation in Savar; A Case Study of Sub-Urban Changes, Department of Urban and Regional Planning, Bangladesh University of Engineering and Technology.
Available at: http://lib.buet.ac.bd:808o/xmlui/ bitstream/handle/123456789/2121/Full\%20\%20Thesis \%20.pdf?sequence $=1 \&$ isAllowed $=\mathrm{y}$. Last accessed: December, 10, 2016.

[5] Tariq, S. H., Jinia, M. A. (2012), Analyzing the relationship between the integration core of DhakaAricha highway and existing land use categories at Savar, Dhaka, Bangladesh through space syntax analysis, International Journal of Scientific Knowledge, Volume 1 Issue 4. Available at: http:// www. ijsk. org/uploads/3/1/1/7/3117743/space_syntax_analysis.p df. Last accessed: May, 5, 2016.

[6] Sarker, P. K. (2012), Save Savar from further degradation, The Daily Star. Available at: http://archive.thedailystar.net/newDesign/newsdetails.php? nid=235694. Last Accessed: April, 5, 2016. [7] BBS (2001), Bangladesh Population Census 2001, Ministry of Planning. Bangladesh.

[8] BBS (2011), Bangladesh Population Census 2011, Ministry of Planning, Bangladesh.

[9] Rashid, M. S. (2003), A study of land transformation in Savar Upazila, Bangladesh, 19152001: an integrated approach using remote sensing, census, map and field data. Doctoral thesis, Durham University. Available at: http://etheses.dur.ac. uk/ 1064/ 1/1064.pdf?EThOS\%20\%28BL\%29. Last accessed: May, 5, 2016.

[10] Akther, F., Hossain, N. S. M. (2011), Impacts of Private Residential Land Development Projects in the Flood Flow Zones of DMDP Area: Case Study of Tetuljhora Union, Journal of Bangladesh Institute of Planners, Vol. 4, pp. 57-70.

[11] Planning Strategy for Rural Northern Ireland (2010), Regional planning policies: Policy DES 7 ribbon development and infill, Department of Environment, Ireland. Available at: http://www. Planningni.gov.uk/index/policy/policy_publications/ru ral_strategy/psrni_regional_policies/psrni_design/psr ni_deso8.htm. Last Accessed: May, 5, 2016.

[12] Masud, M. B. (2008), Land-use change in Savar Municipality: 1974-2001 (in press), Jahangirnagar University, Savar, Dhaka.

[13] Islam, I. (2006), Wetland of Dhaka: Alarming depletion, The Daily Star. Available at http:// www. the dailystar.net/2006/05/19/d605191902113.htm. Last accessed: April 30, 2016., Vol. 4, pp. 57-70.

[14] Ronald, R. F. (1959), Methods of studying ribbon development in urban areas study area: The Oklahoma City - Norman Area. Available at: http:// digital.library.okstate.edu/oas/oas_pdf/v41/p177_180. pdf. Last accessed: August, 8, 2016.

[15] Sharif, M. S., Esa, A. J. (2014), Dynamics of land price and land use change: A case of Savar Municipality, Bangladesh, Journal of South Asian Studies, vol. 2, issue 1, pp. 83-89. Available at: http://escijournals.net/JSAS/article/view/226/276.pdf . Last accessed: April, 10, 2014. 
[16] Arefin, S. (2014), Prohibit ribbon development, The Daily Star. Available at: http:// www.thedailystar. net /prohibit -ribbon -development-22007, Last Accessed: June, 27, 2016.

[17] Rangwala, S. C. (1999), Town Planning, India: R.P. Patel, Rupalee Publications.

[18] Asadi et al. (2015), Take a Look at the Main Impacts of Agricultural Land Use Change in Iran, International Journal of Environmental Science and Development, vol. 6, issue 7, pp. 539-542 Available at: www.ijesd.org/vol6/652-R3003.pdf. Last accessed: November, 10, 2016.

[19] Rafiq et al. (2014), Conserving Wetlands: Valuation of Indirect Use Benefits of a Wetland of Dhaka, International Journal of Environmental Science and Development, vol. 5, issue 1, pp. 64-69. Available at: www.ijesd.org/papers/452-P015.pdf. Last accessed: November, 10, 2016.

[20] Khan, N. I. (2000), Temporal Mapping and Spatial Analysis of Land Transformation due to Urbanization and Its Impact on Surface Water System: A Case rom Dhaka Metropolitan Area, Bangladesh, International Archives of Photogrammetry and Remote Sensing, vol. 31, pp. 598-605. Available at: www.isprs.org/proceedings/XXXIII/congress/part7/59 8_XXXIII-part7.pdf. Last accessed: November, 10, 2016.

[21] Prasad et al. (2009), Is Rapid Urbanization Leading to Loss of Water Bodies?, Journal of Spatial Science, vol. 2, pp. 43-52. Available at: www.soulhyd.org/articles/MS_JSS_waterbodies.pdf. Last accessed: December, 10, 2016.

[22] National Highway Act (1956), Ministry of Communication. Available at: http://transport. bih.nic.in/ Acts /The-National-Highways-Act-1956.pdf. Last accessed: November, 07, 2016.

[23] GoB (2001), National Land-use Policy, Ministry of Land, Dhaka Gazette, Extraordinary, Dhaka.

[24] Bombay Highways Act (1955), Standards for Building Lines and Control Lines. Available at: http://www.mahapwd.com/noobjectioncertificate/ribb ondevelopment.html. Last Accessed: December, 15, 2016. 